日植病報 $46: 582-593(1980)$

Ann. Phytopath. Soc. Japan $46: 582-693$ (1980)

\title{
On the Virulence Analysis of Pathogen Race Frequencies
}

\author{
Shigehisa KIYOSAWA* \\ 清沢茂久*：病原菌レース頻度の病原性分析について
}

\begin{abstract}
The ratio of observed value to expected value of genotype $A v-i^{+} A v-k^{+}$for virulence in blast fungus (abbreviated as ++ genotype ratio) was studied using the available data in Japan. The ++ genotype ratios were higher than one in almost all years in all ten districts. The ++ genotype frequencies decreased during seven years from 1959 to 1965, with decrease of frequencies of individual virulence genes, $A v-i^{+}$and $A v-k^{+}$, except Hokkaido. In Niigata, Toyama, Yamagata and Kanagawa Prefectures, significant differences are found between expected and observed values in various genotypes for virulence during the period from 1964 to 1966. The results of simulations and mathematical analysis on the change of ++ genotype ratio indicate that the ++ genotype ratio becomes temporarily higher than one when $p_{2} r_{2} p_{3} r_{3} / p_{1} r_{1} p_{4} r_{4}<Q_{4} /\left(Q_{2}+Q_{4}\right)\left(Q_{3}+Q_{4}\right)$ and lower than one when $p_{2} r_{2} p_{3} r_{3} / p_{1} r_{1} p_{4} r_{4}>$ $Q_{4} /\left(Q_{2}+Q_{4}\right)\left(Q_{3}+Q_{4}\right)$. The ++ genotype ratio asymptotically approaches to 1 under conditions where the frequency of ++ genotype continues to increase and to 0 when it continues to decrease. The change of frequencies of ++ genotype (race) cannot be explained by simple directional and stabilizing selections. The ++ genotype ratio returns to 1 even after directional and/or stabilizing selections, and this limits the use of virulence analysis to search for the causes of the change of pathogen genotype (race) frequencies. The ratio of observed value to expected one in various genotypes (especially ++ genotype) may help the studies in a sense that the use of the ratio reduces the range or kinds of factors which must be examined.
\end{abstract}

(Received May 22, 1980)

\section{Introduction}

Accroding to Wolfe $e t$ al. ${ }^{14)}$, who studied the relationship between frequencies of genes and genotypes for virulence in powdery mildew population on barley, the following extrapolation from studies on barley powdery mildew should be possible in the ideal model of host-pathogen systems with gene-for-gene relationship in their disease reaction.

(1) The frequency of occurrence of pairs, triplets etc. of virulence genes is the product of the total frequencies of the individual virulence genes involved.

(2) If we wish to calculate the frequency of the genotype which has only $a, b$ and $d$ virulence, as opposed to all combinations which include $a, b$ and $d$, then the product of frequencies of $a, b$ and $d\left(=p_{a} p_{b} p_{d}\right)$ has to be multiplied by the product of the frequencies of remaining alleles for non-virulence in the groups i.e. in this case, $q_{c}$, and $q_{e}$, viz.

frequency of $a b C d E=p_{a} p_{b} p_{d} q_{c} q_{e}$.

\footnotetext{
* National Institute of Agricultural Sciences, Yatabe, Tsukuba, Ibaraki 305, Japan 農業技術研究所
} 
(3) If we relate this to a haploid pathogen such as Erysiphe graminis, the causal agent of cereal powdery mildews, where phenotype frequencies are equal to gene frequencies, the rules of the ideal model and its extrapolations should also apply to collections of field data, given the following assumptions :

(i) the pathogen.populations sampled are large,

(ii) reassortment of virulence genes is random and independent,

(iii) there is no differential selection for the genes or gene combinations involved.

The following assumptions should be added to these three:

(iv) the pathogen isolates must be drawn from the same population (Wolfe, personal communication),

(v) mutations of an avirulence allele to virulence occur independently of mutations in other virulence loci.

These principles were used for analyzing race frequencies of the pathogen ${ }^{11,15)}$, of ten called virulence analysis ${ }^{15}$. In this paper, computor simulation and theoretical studies on the race frequency were carried out, and it was revealed that the state in the item (2) mentioned above would be obtained even after some selections in fungal population by resistance genes in addition to conditions assumed by Wolfe et al. ${ }^{14)}$ Based on these simulation and theoretical studies, the results of the virulence analysis of data on rice blast, Pyricularia oryzae, were discussed.

\section{Virulence analysis of race frequencies of blast fungus}

To know race frequencies of the pathogen, random sampling is required. However, most of past studies on race of blast fungus in Japan were not always carried out in random sampling, because virulent races were isolated from the varieties with a special resistance gene.

There are two methods to obtain information on race frequencies from the data without random sampling. One is to calculate race frequencies from the isolates which were isolated from varieties without true-resistance genes. The other method is that the race frequencies obtained from the data without random sampling are weighted by frequencies of resistance genes in varieties in each region and by disease severity on these varieties.

The first method was used to estimate the frequencies of genotypes of the isolates. From the data by Goto et al..$^{2)}$ and Kozaka et al. ${ }^{10)}$, only fungal isolates which were taken from varieties without true-resistance genes and with gene $P i-a$ were chosen to know their genotypes for virulence. Goto et al. ${ }^{2)}$ and Kozaka et al. ${ }^{10)}$ identified the isolates by using 12 differential varieties. Since almost all of these differential varieties do not have single resistance genes ${ }^{4}$, it is difficult to know the genotype for virulence of each isolate in relation to all resistance genes included in the differential varieties from their data. Three differential varieties have, however, been known to have single genes, $P i-a$ in Aichi Asahi ${ }^{6)}, P i-i$ in Ishikari Shiroke ${ }^{19)}$ and $P i-k$ in Kanto $51^{19}$. Therefore, genotypes for virulence corresponding to these three true-resistance genes were determined for the chosen isolates, based on reactions on the three varieties, Aichi Asahi, Ishikari Shiroke and Kanto 51. The symbols, $A v-a, A v-i$ and $A v-k$ were given to isolates avirulent to varieties with $P i-a, P i-i$ and $P i-k$, respectively, and the symbols, $A v-a^{+}, A v-i^{+}$and $A v-k^{+}$, were given to virulence genes to varieties with $P i-a, P i-i$ and $P i-k$, respectively. 
Table 1. Change of frequencies of virulence genes and genotypes in various districts

\begin{tabular}{|c|c|c|c|c|c|c|c|c|c|c|}
\hline \multirow{2}{*}{ District } & \multirow{2}{*}{\multicolumn{2}{|c|}{$\begin{array}{l}\text { Gene or } \\
\text { genotye }\end{array}$}} & \multicolumn{7}{|c|}{ Year } & \multirow{2}{*}{$\begin{array}{c}\text { Regression } \\
\text { coefficient } \\
\text { (significance) }\end{array}$} \\
\hline & & & 1959 & 1960 & 1961 & 1962 & 1963 & 1964 & 1965 & \\
\hline \multirow{4}{*}{ Hokkaido } & \multirow{2}{*}{\multicolumn{2}{|c|}{$\begin{array}{l}A v-i^{+} \\
A v-k^{+}\end{array}$}} & 66.7 & 58.3 & 82.4 & 85.4 & 66.7 & 47.6 & 43.6 & -0.380 \\
\hline & & & 27.8 & 25.0 & 47.1 & 54.9 & 34.5 & 57.1 & 35.9 & 0.270 \\
\hline & \multirow{2}{*}{++} & Obs. & 27.8 & 25.0 & 47.1 & $\mathbf{5 2 . 4}$ & 34.5 & 38.1 & 26.9 & 0.389 \\
\hline & & Expt. & 18.5 & 14.5 & 38.8 & 46.9 & 23.0 & 27.2 & 15.7 & 0.429 \\
\hline \multirow{4}{*}{ Tohoku } & \multirow{2}{*}{\multicolumn{2}{|c|}{$\begin{array}{l}A v-i^{+} \\
A v-k^{+}\end{array}$}} & 77.8 & 87.8 & 80.0 & 9.5 & 67.4 & 46.2 & 55.7 & -0.579 \\
\hline & & & 43.1 & 63.4 & 61.3 & 9.5 & 43.5 & 53.8 & 45.5 & -0.106 \\
\hline & \multirow{2}{*}{++} & Obs. & 43.1 & 63.4 & 61.3 & 9.5 & 43.5 & 30.8 & 31.8 & -0.418 \\
\hline & & Expt. & 33.5 & 55.7 & 49.0 & 0.9 & 29.3 & 24.9 & 25.3 & -0.378 \\
\hline \multirow{4}{*}{ Kanto } & \multirow{4}{*}{\multicolumn{2}{|c|}{$\begin{array}{ll}A v-i^{+} & \\
A v-k^{+} & \\
++ & \text {Obs. } \\
& \text { Expt. }\end{array}$}} & 54.8 & 28.2 & 25.0 & 57.1 & 0.0 & 8.8 & 16.1 & -0.643 \\
\hline & & & 32.3 & 25.6 & 25.0 & 42.9 & 0.0 & 5.9 & 16.1 & -0.404 \\
\hline & & & 32.3 & 23.1 & 12.5 & 42.9 & 0.0 & 5.9 & 16.1 & -0.341 \\
\hline & & & 17.7 & 7.2 & 6.3 & 24.5 & 0.0 & 0.5 & 2.6 & -0.232 \\
\hline \multirow{4}{*}{ Hokuriku } & \multirow{4}{*}{\multicolumn{2}{|c|}{$\begin{array}{ll}A v-i^{+} & \\
A v-k^{+} & \\
++ & \text {Obs. } \\
& \text { Expt. }\end{array}$}} & 68.4 & 50.0 & 19.2 & 31.3 & 26.7 & 0.0 & 15.6 & $-0.896^{*}$ \\
\hline & & & 316 & 50.0 & 7.7 & 6.3 & 0.0 & 0.0 & 18.9 & -0.521 \\
\hline & & & 31.6 & 50.0 & 0.0 & 6.3 & 0.0 & 0.0 & 14.4 & -0.541 \\
\hline & & & 21.6 & 25.0 & 1.2 & 2.0 & 0.0 & 0.0 & 2.9 & $-0.383^{*}$ \\
\hline \multirow{4}{*}{ Tosan } & \multirow{4}{*}{\multicolumn{2}{|c|}{$\begin{array}{ll}A v-i^{+} & \\
A v-k^{+} & \\
++ & \text {Obs. } \\
& \text { Expt. }\end{array}$}} & 57.9 & 50.0 & 42.0 & 4.8 & 20.9 & 20.8 & 38.9 & -0.472 \\
\hline & & & 44.7 & 25.9 & 35.0 & 0.0 & 7.0 & 8.3 & 0.0 & $-0.705^{*}$ \\
\hline & & & 42.1 & 25.9 & 25.0 & 0.0 & 7.0 & 8.3 & 0.0 & $-0.641^{* *}$ \\
\hline & & & 29.4 & 12.9 & 14.0 & 0.0 & 1.5 & 1.7 & 0.0 & $-0.440^{* *}$ \\
\hline \multirow{4}{*}{ Tokai } & \multirow{4}{*}{\multicolumn{2}{|c|}{$\begin{array}{cc}A v-i^{+} & \\
A v-k^{+} & \\
++ & \text {Obs. } \\
& \text { Expt. }\end{array}$}} & 31.9 & 46.3 & 44.4 & 52.8 & 21.4 & 20.8 & 14.3 & -0.453 \\
\hline & & & 12.8 & 29.3 & 3.7 & 5.7 & 7.1 & 8.3 & 11.4 & -0.153 \\
\hline & & & 8.5 & 24.4 & 3.7 & 5.7 & 7.1 & 8.3 & 5.7 & -0.133 \\
\hline & & & 4.1 & 13.6 & 1.6 & 3.0 & 1.5 & 1.7 & 1.6 & -0.112 \\
\hline \multirow{4}{*}{ Kinki } & \multirow{4}{*}{$\begin{array}{c}A v-i^{+} \\
A v-k^{+} \\
++\end{array}$} & & 50.0 & & 44.4 & 33.3 & 15.9 & & 93 & $-0.753^{* *}$ \\
\hline & & & 25.0 & & 11.1 & 0.0 & 2.3 & & 0.0 & $-0.419^{*}$ \\
\hline & & Obs. & 25.0 & & 11.1 & 0.0 & 0.0 & & 0.0 & $-0.431^{*}$ \\
\hline & & Expt. & 12.5 & & 4.9 & 0.0 & 0.4 & & 0.0 & $-0.210^{*}$ \\
\hline \multirow{4}{*}{ Chugoku } & \multirow{4}{*}{$\begin{array}{c}A v-i^{+} \\
A v-k^{+} \\
++\end{array}$} & & 43.8 & 80.0 & 25.0 & 50.7 & 46.1 & 23.2 & 28.8 & -0.491 \\
\hline & & & 6.3 & 10.0 & 12.5 & 6.8 & 3.8 & 5.3 & 2.8 & -0.102 \\
\hline & & Obs. & 6.3 & 10.0 & 12.5 & 6.8 & 2.6 & 5.3 & 1.1 & -0.125 \\
\hline & & Expt. & 2.7 & 8.0 & 3.1 & 3.5 & 1.8 & 1.2 & 0.8 & -0.736 \\
\hline \multirow{4}{*}{ Shikoku } & $A v-i^{+}$ & & 22.2 & 57.1 & 50.0 & 50.0 & 11.1 & 37.5 & 15.0 & -0.356 \\
\hline & $A v-k^{+}$ & & 33.3 & 21.4 & 0.0 & 14.3 & 0.0 & 8.3 & 5.0 & -0.397 \\
\hline & & Obs. & 22.2 & 21.4 & 0.0 & 14.3 & 0.0 & 8.3 & 2.5 & -0.305 \\
\hline & & Expt. & 7.4 & 12.2 & 0.0 & 3.1 & 0.0 & 3.1 & 0.8 & -0.136 \\
\hline & $A v-i^{+}$ & & 92.7 & 33.8 & 50.0 & 0.0 & 0.0 & 4.1 & 1.5 & $-0.137^{*}$ \\
\hline & $A v-k^{+}$ & & 48.8 & 20.6 & 16.7 & 5.9 & 0.0 & 8.2 & 6.2 & $-0.664^{*}$ \\
\hline Ay usmu & & Obs. & 48.8 & 17.6 & 16.7 & 0.0 & 0.0 & 1.4 & 0.0 & $-0.698^{*}$ \\
\hline & & Expt. & 45.2 & 7.0 & 8.0 & 0.0 & 0.0 & 0.3 & 0.1 & -0.560 \\
\hline
\end{tabular}


Frequencies of virulence genes, $A v-a^{+}, A v-i^{+}$and $A v-k^{+}$, in 10 districts during 8 years varied from 58 to $100 \%$ with mean $92 \%, 0$ to 100 with mean 66 and 0 to 95 with mean 35 , respectively. Frequencies of $A v-a^{+}$were generally very high, and their variations among prefectures and among years were very little. Therefore, frequencies of $A v-a^{+}$gene are not effective in studying race frequency change. So far as the frequencies of genotypes involving $A v-i$ and $A v-k$ genes are concerned, they did not differ between isolates from varieties without resistance genes known up to now (" + " varieties) and ones from varieties with only $P i-a$ (" $P i-a$ " varieties). Therefore, frequencies of all possible combinations composed of $A v-i$ and $A v-k$ genes, $A v-i A v-k, A v-i^{+} A v-k$ (referring to + $A v-k$, hereafter), $A v-i A v-k^{+}(A v-i+)$ and $A v-i^{+} A v-k^{+}(++)$, were calculated for the isolates from " + " varieties and " $P i-a$ " varieties.

Frequencies of each virulence gene and pathogen genotype, ++ , are shown in Table 1 , with the expected value of ++ genotype which is the product of frequencies of virulence genes, $A v-i^{+}$and $A v-k^{+}$. Frequencies of genes, $A v-i^{+}$and $A v-k^{+}$, and genotype, ++ , decreased during seven years from 1959 to 1965 in all districts except Hokkaido district.

The expected values of the ++ genotype are lower than the observed values in almost all districts and in almost all years.

The difference between observed and expected values is not always significant. Differences between expected and observed values were also found in race frequencies in Niigata (Table 2), Toyama (Table 3), Yamagata (Table 4) and Kanagawa (Table 5) Prefectures, although not found in Gifu Prefecture (Table 6).

Table 2. Virulence analysis of frequencies of pathogen genotypes in Niigata Prefecture (after Yamada and Iwano, 1975 ${ }^{17}$ )

\begin{tabular}{|c|c|c|c|c|c|c|c|c|c|c|}
\hline \multirow{2}{*}{ Genotype } & \multicolumn{2}{|c|}{$1961-1963$} & \multicolumn{2}{|c|}{$1964-1965$} & \multicolumn{2}{|c|}{1965} & \multicolumn{2}{|c|}{1966} & \multicolumn{2}{|c|}{1969} \\
\hline & $\begin{array}{l}\text { Ob- } \\
\text { served }\end{array}$ & Expected & $\begin{array}{l}\text { Ob- } \\
\text { served }\end{array}$ & Expected & $\begin{array}{l}\text { Ob- } \\
\text { served }\end{array}$ & Expected & $\begin{array}{l}\text { Ob- } \\
\text { served }\end{array}$ & Expected & $\begin{array}{l}\text { Ob- } \\
\text { served }\end{array}$ & Expected \\
\hline$a i k$ & 0.03 & 0.022 & 0.14 & $0.053^{* *}$ & 0.21 & $0.108^{*}$ & 0.18 & $0.061^{* *}$ & 0.02 & 0.023 \\
\hline$+i k$ & 0.71 & 0.696 & 0.26 & 0.200 & 0.38 & 0.359 & 0.26 & 0.230 & 0.20 & 0.211 \\
\hline$a+k$ & & & & 0.043 & & $0.055^{* *}$ & & $0.054^{*}$ & & 0.003 \\
\hline$a i+$ & & & 0.02 & 0.062 & 0.02 & 0.045 & 0.01 & 0.050 & 0.07 & 0.067 \\
\hline$a++$ & & & 0.04 & 0.051 & & 0.023 & & $0.044^{*}$ & & 0.007 \\
\hline$+i+$ & & 0.022 & 0.12 & $0.235^{*}$ & 0.05 & 0.150 & 0.05 & $0.188 * *$ & 0.60 & 0.599 \\
\hline$++k$ & 0.23 & 0.245 & 0.05 & $0.164^{* *}$ & 0.12 & 0.183 & 0.09 & $0.204^{* *}$ & 0.03 & 0.023 \\
\hline+++ & 0.03 & 0.008 & 0.36 & $0.192^{* *}$ & 0.21 & $0.076^{* *}$ & 0.38 & $0.167^{* *}$ & 0.07 & 0.074 \\
\hline $\begin{array}{l}\text { No. of } \\
\text { isolates }\end{array}$ & & 31 & & 95 & & 124 & & 04 & & 137 \\
\hline
\end{tabular}

$a, i$ and $k$ are abbreviations of avirulence genes, $A v-a, A v-i$ and $A v-k$, and + is the virulence allele of each avirulence gene. $\chi^{2}$ test was carried out only on genotypes which have expected number greater than 1. 
Table 3. Virulence analysis of frequencies of pathogen genotypes in Toyama Prefecture (after Yamada and Iwano, 1975 ${ }^{17}$ )

\begin{tabular}{|c|c|c|c|c|c|c|c|c|}
\hline \multirow{2}{*}{ Genotype } & \multicolumn{2}{|c|}{$1959-1962$} & \multicolumn{2}{|c|}{$1964-1965$} & \multicolumn{2}{|c|}{1966} & \multicolumn{2}{|c|}{1970} \\
\hline & Observed & Expected & Observed & Expected & Observed & Expected & Observed & Expected \\
\hline$a i k$ & 0.08 & 0.200 & & $0.106^{*}$ & & $0.086^{* *}$ & & 0.006 \\
\hline$+i k$ & 0.50 & 0.540 & 0.29 & $0.134^{* *}$ & 0.56 & $0.451^{* *}$ & 0.60 & 0.620 \\
\hline$a+k$ & & & 0.02 & 0.036 & & 0.012 & 0.01 & 0.002 \\
\hline$a i+$ & & & 0.22 & 0.223 & 0.12 & $0.055^{* *}$ & & 0.001 \\
\hline$a++$ & & & 0.20 & $0.076^{* *}$ & 0.03 & $0.008^{* *}$ & & \\
\hline$+i+$ & & & 0.24 & 0.283 & 0.18 & $0.288^{* *}$ & 0.11 & 0.093 \\
\hline$++k$ & 0.19 & 0.161 & 0.02 & 0.046 & 0.03 & $0.062^{*}$ & 0.26 & 0.241 \\
\hline+++ & 0.04 & 0.067 & 0.02 & $0.096^{*}$ & 0.06 & 0.039 & 0.02 & 0.036 \\
\hline $\begin{array}{l}\text { No. of } \\
\text { isolates }\end{array}$ & \multicolumn{2}{|c|}{26} & \multicolumn{2}{|c|}{59} & \multicolumn{2}{|c|}{235} & \multicolumn{2}{|c|}{90} \\
\hline
\end{tabular}

See the footnote of Table 2 .

Table 4. Virulence analysis of frequencies of pathogen genotypes in Yamagata Prefecture (after Yanagita, Yaegashi and Mogi, $1972^{203}$

\begin{tabular}{|c|c|c|c|c|c|c|c|c|c|}
\hline \multirow{2}{*}{ Genotype } & \multicolumn{3}{|c|}{1966} & \multicolumn{3}{|c|}{1967} & \multicolumn{3}{|c|}{1968} \\
\hline & \multicolumn{2}{|c|}{ Observed } & $\begin{array}{c}\text { Expected } \\
\text { Rate }\end{array}$ & \multicolumn{2}{|c|}{ Observed } & $\begin{array}{c}\text { Expected } \\
\text { Rate }\end{array}$ & \multicolumn{2}{|c|}{ Observed } & $\begin{array}{c}\text { Expected } \\
\text { Rate }\end{array}$ \\
\hline$+i k$ & 12 & 0.353 & 0.202 & 120 & 0.492 & $0384 * *$ & 39 & 0.371 & 0.291 \\
\hline$a i+$ & 3 & 0.088 & 0.022 & 3 & 0.012 & 0.002 & 1 & 0.010 & 0.002 \\
\hline$a++$ & & & 0.025 & 1 & 0.004 & 0.002 & & & 0.002 \\
\hline$+i+$ & 1 & 0.029 & $0.227^{* *}$ & 6 & 0.025 & $0.136^{* *}$ & 14 & 0.133 & $0.218^{*}$ \\
\hline$++k$ & 4 & 0.118 & 0.227 & 60 & 0.246 & $0.342^{* * *}$ & 21 & 0.200 & 0.275 \\
\hline+++ & 14 & 0.412 & $0.256^{*}$ & 54 & 0.221 & $0.122^{* * *}$ & 30 & 0.286 & $0.206^{*}$ \\
\hline $\begin{array}{l}\text { No. of } \\
\text { isolates }\end{array}$ & 34 & & & 244 & & & 105 & & \\
\hline
\end{tabular}

See the footnote of Table 2 .

Table 5. Virulence analysis of frequencies of pathogen genotypes in Kanagawa Prefecture (after Yabuki and Kiyosawa ${ }^{16)}$ )

\begin{tabular}{ll|cccc|c}
\hline & & $A v-a A v-k$ & $A v-a A v-k^{+}$ & $A v-a^{+} A v-k$ & $A v-a^{+} A v-k^{+}$ & Total \\
\hline \multirow{2}{*}{ Observed } & No. & 0 & 92 & 30 & 20 & 142 \\
Expected & Rate & 0.000 & 0.648 & 0.211 & 0.141 & 1.000 \\
\hline \multirow{2}{*}{$\chi^{2}$ value } & Individual & $22.54^{* *}$ & $10.67^{* *}$ & $38.89^{* *}$ & $13.28^{* *}$ & \\
& Overall & & \multicolumn{2}{|c|}{$70.27^{* *}$} & & \\
\end{tabular}

** Indicating that the difference is significant at the $1 \%$ level. 
Ann. Phytopath. Soc. Japan 46 (5). December, 1980

Table 6. Virulence analysis of frequencies of pathogen genotypes in Gifu Prefecture (after Kiyosawa, Yasuda and Shintani, 1977')

\begin{tabular}{|c|c|c|c|c|c|c|c|c|c|c|c|}
\hline Genotype & \multicolumn{2}{|c|}{$\begin{array}{l}\text { Observed } \\
\text { No. Rate }\end{array}$} & $\begin{array}{c}\text { Expected } \\
\text { Rate }\end{array}$ & Genotype & \multicolumn{2}{|c|}{$\begin{array}{l}\text { Observed } \\
\text { No. Rate }\end{array}$} & $\begin{array}{c}\text { Expected } \\
\text { Rate }\end{array}$ & Genotype & \multicolumn{2}{|c|}{$\begin{array}{l}\text { Observed } \\
\text { No. Rate }\end{array}$} & $\begin{array}{c}\text { Expected } \\
\text { Rate }\end{array}$ \\
\hline$a i k$ & 1 & .0135 & .0025 & $a i k$ & 10 & .1351 & .1837 & $a i k$ & 0 & .0000 & .0049 \\
\hline$+i k$ & 12 & .1621 & .1891 & $+i k$ & 17 & .2297 & .2047 & $+i k$ & 27 & .3648 & .3835 \\
\hline$a+k$ & 0 & .0000 & .0028 & $a+k$ & 22 & .2972 & .2696 & $a+k$ & 0 & .0000 & .0076 \\
\hline$a i+$ & 0 & .0000 & .0038 & $a i+$ & 3 & .0405 & .0077 & $a i+$ & 1 & .0135 & .0002 \\
\hline$a++$ & 0 & .0000 & .0042 & $a++$ & 0 & .0000 & .0113 & $a++$ & 0 & .0000 & .0002 \\
\hline$+i+$ & 22 & .2972 & .2773 & $+i+$ & 0 & .0000 & .0086 & $+i+$ & 2 & .0270 & .0161 \\
\hline$++k$ & 17 & .2297 & .2107 & $++k$ & 22 & .2972 & .3004 & $++k$ & 44 & .5944 & .5624 \\
\hline+++ & 22 & .2972 & .3090 & +++ & 0 & .0000 & .0126 & +++ & 0 & .0000 & .0241 \\
\hline $\begin{array}{l}\text { No. of } \\
\text { isolates }\end{array}$ & 74 & & & & 74 & & & & 74 & & \\
\hline
\end{tabular}

$a, i, k$ and $z$ are abbreviations of avirulence genes, $A v-a, A v-i, A v-k$ and $A v-z$, and + is the virulence allele of each avirulence gene.

Analysis was performed after dividing to three combinations composed of three genes among four genes for avirulence. since the number of isolates collected is too little to use the $\chi_{2}$ test. A test was carried out only on genotypes which have expected number greater than 1.

Significant difference was not recognized between observed and expected values.

\section{Causes of disagreement between observed and expected values}

The followings are considered as causes of the disagreement or deviation from 1 of the ratio of observed value to expected one.

a) Directional selection*: growing of resistant varieties stimulates the increase of pathogen genotype virulent to the resistant varieties ${ }^{2,21}$.

b) Stabilizing selection*: the difference of fitness between fungus strains leads to selection of fungus strain with high fitness, resulting in stabilizing selection ${ }^{17}$.

c) Random genetic drift**: when the number of fungus overwintering or oversummering is small, the genotype frequencies are determined by frequencies of types survived by chance? ${ }^{7}$.

d) Invasion of fungus from outside sources?

e) Difference due to varieties from which the fungus was isolated: only isolates virulent to the varieties are collected ${ }^{18}$.

f) Difference due to places where the fungus was isolated: distributing pathogen genotypes are different due to varieties in surrounding field if they have specific resistance genes and probably due to environmental conditions.

g) Difference due to season when the fungus was isolated: seasonal variation of pathogen genotype frequency was of ten found ${ }^{5}$.

h) Sampling error.

i) Change of genotype frequencies due to environmental conditions.

j) Error in the test for pathogenicity: the use of unsuitable differential varieties and unskilled operation lead to incorrect result.

Among these causes, all except the first two should be unable to estimate previously,

* Used in the definition as van der Plank' ${ }^{13)}$ did.

** Used on the basis of definition by Crow and Kimura'1. 
but a part of them can be partially eliminated by improvement of methods for estimating genotype frequencies. Only two, random genetic drift and invasion of fungus from outside sources, cannot be eliminated in the field-plot tests.

The method to predict the change of the ratio of observed value to expected one in ++ pathogen genotype frequencies due to the first two causes is not yet exploited. An attempt to predict this ratio (referring to the ++ genotype ratio, hereafter) is mentioned in the next section.

\section{Change of the ++ genotype ratio by directional and stabilizing selections}

Let us consider a host-pathogen system with 2 gene-pairs for resistance (A, B) and avirulence $(a b)$. Frequencies of pathogen genotypes, $a b, a+,+b$ and ++ , in each generation $\left(\mathrm{p}_{1}{ }^{\prime}, \mathrm{p}_{2}{ }^{\prime}, \mathrm{p}_{3}{ }^{\prime}\right.$ and $\mathrm{p}_{4}{ }^{\prime}$, respectively) are shown as follows ${ }^{8)}$.

$$
\begin{aligned}
& \mathrm{p}_{1}{ }^{\prime}=\mathrm{p}_{1} \mathrm{r}_{1} \mathrm{Q}_{4} /\left[\mathrm{p}_{1} \mathrm{r}_{1} \mathrm{Q}_{4}+\mathrm{p}_{2} \mathrm{r}_{2}\left(\mathrm{Q}_{3}+\mathrm{Q}_{4}\right)+\mathrm{p}_{3} \mathrm{r}_{3}\left(\mathrm{Q}_{2}+\mathrm{Q}_{4}\right)+\mathrm{p}_{4} \mathrm{r}_{4}\right], \\
& \mathrm{p}_{2}{ }^{\prime}=\mathrm{p}_{22} \mathrm{r}_{2}\left(\mathrm{Q}_{3}+\mathrm{Q}_{4}\right) /\left[\mathrm{p}_{1} \mathrm{r}_{1} \mathrm{Q}_{4}+\mathrm{p}_{2} \mathrm{r}_{2}\left(\mathrm{Q}_{3}+\mathrm{Q}_{4}\right)+\mathrm{p}_{3} \mathrm{r}_{3}\left(\mathrm{Q}_{2}+\mathrm{Q}_{4}\right)+\mathrm{p}_{4} \mathrm{r}_{4}\right] \text {, }
\end{aligned}
$$

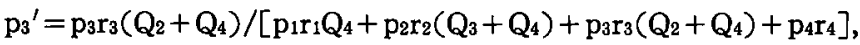

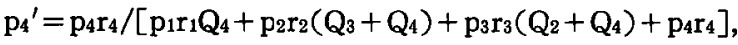

where $p_{1}, p_{2}, p_{3}$ and $p_{4}$ are genotype frequencies in the foregoing generation, $r_{1}, r_{2}, r_{3}$ and $r_{4}$ are multiplication ability or fitness in pathogen genotypes, $a b, a+,+b$ and ++ , respectively. $\mathrm{Q}_{1}, \mathrm{Q}_{2}, \mathrm{Q}_{3}$ and $\mathrm{Q}_{4}$ are, respectively,

$$
\begin{aligned}
& \mathrm{Q}_{1}=\mathrm{q}_{1} \mathrm{~s}_{1} /\left(\mathrm{q}_{1} \mathrm{~s}_{1}+\mathrm{q}_{2} \mathrm{~S}_{2}+\mathrm{q}_{3} \mathrm{~S}_{3}+\mathrm{q}_{4} \mathrm{~S}_{4}\right) \\
& \mathrm{Q}_{2}=\mathrm{q}_{22} /\left(\mathrm{q}_{1} \mathrm{~s}_{1}+\mathrm{q}_{2} \mathrm{~s}_{2}+\mathrm{q}_{3 \mathrm{~s}_{3}}+\mathrm{q}_{4} \mathrm{~s}_{4}\right) \\
& \mathrm{Q}_{3}=\mathrm{q}_{3} \mathrm{~s}_{3} /\left(\mathrm{q}_{1} \mathbf{s}_{1}+\mathrm{q}_{2} \mathrm{~s}_{2}+\mathrm{q}_{3} \mathrm{~s}_{3}+\mathrm{q}_{4} \mathrm{~s}_{4}\right) \\
& \mathrm{Q}_{4}=\mathrm{q}_{4} \mathrm{~s}_{4} /\left(\mathrm{q}_{1} \mathrm{~s}_{1}+\mathrm{q}_{2} \mathrm{~s}_{2}+\mathrm{q}_{3} \mathrm{~s}_{3}+\mathrm{q}_{4} \mathrm{~s}_{4}\right)
\end{aligned}
$$

where $q_{1}, q_{2}, q_{3}$ and $q_{4}$ are percent growing areas of host genotypes, $A B, A+,+B$ and ++ , and $s_{1}, s_{2}, s_{3}$ and $s_{4}$ are their relative field susceptibility.

Conditions where expected value of ++ genotype frequency equals observed value can be expressed as follows.

$$
\left(\mathrm{p}_{2}{ }^{\prime}+\mathrm{p}_{4}{ }^{\prime}\right)\left(\mathrm{p}_{3}{ }^{\prime}+\mathrm{p}_{4}{ }^{\prime}\right)=\mathrm{p}_{4}{ }^{\prime} .
$$

Substituting equation (1),

$$
\begin{aligned}
& \frac{\left[p_{2} r_{2}\left(Q_{3}+Q_{4}\right)+p_{4} r_{4}\right]\left[p_{3} r_{3}\left(Q_{2}+Q_{4}\right)+p_{4} r_{4}\right]}{\left[p_{1} r_{1} Q_{4}+p_{2} r_{2}\left(Q_{3}+Q_{4}\right)+p_{3} r_{3}\left(Q_{2}+Q_{4}\right)+p_{4} r_{4}\right]^{2}} \\
& =\frac{p_{4} r_{4}}{p_{1} r_{1} Q_{4}+p_{2} r_{2}\left(Q_{3}+Q_{4}\right)+p_{3} r_{3}\left(Q_{2}+Q_{4}\right)+p_{4} r_{4}} \\
& =\frac{p_{4} r_{4}\left[p_{1} r_{1} Q_{4}+p_{2} r_{2}\left(Q_{3}+Q_{4}\right)+p_{3} r_{3}\left(Q_{2}+Q_{4}\right)+p_{4} r_{4}\right]}{\left[p_{1} r_{1} Q_{4}+p_{2} r_{2}\left(Q_{3}+Q_{4}\right)+p_{3} r_{3}\left(Q_{2}+Q_{4}\right)+p_{4} r_{4}\right]^{2}} .
\end{aligned}
$$

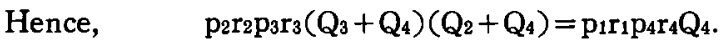

$$
\text { and therefore } \quad \mathrm{p}_{2} \mathrm{r}_{2} \mathrm{p}_{3} \mathrm{r}_{3} / \mathrm{p}_{1} \mathrm{r}_{1} \mathrm{p}_{4} \mathrm{r}_{4}=\mathrm{Q}_{4} /\left(\mathrm{Q}_{3}+\mathrm{Q}_{4}\right)\left(\mathrm{Q}_{2}+\mathrm{Q}_{4}\right) \text {. }
$$

Under this condition, the ++ genotype ratio, (observed value)/(expected value), becomes 1 .

Simulations were performed to know the influence of $r$ 's values or $Q$ 's values on the ++ genotype ratios. Simulations started on the assumption that mutation rates are same between two avirulence genes, $a$ and $b$, and mutations occur independently of each other, i. e. the ++ genotype ratio is 1 . Giving $\mathrm{p}_{2}^{\prime}=0.01$ as an example,

$$
\mathrm{p}_{2}{ }^{\prime}=\mathrm{p}_{\mathrm{a}}{ }^{\prime}=0.01 \text {. }
$$




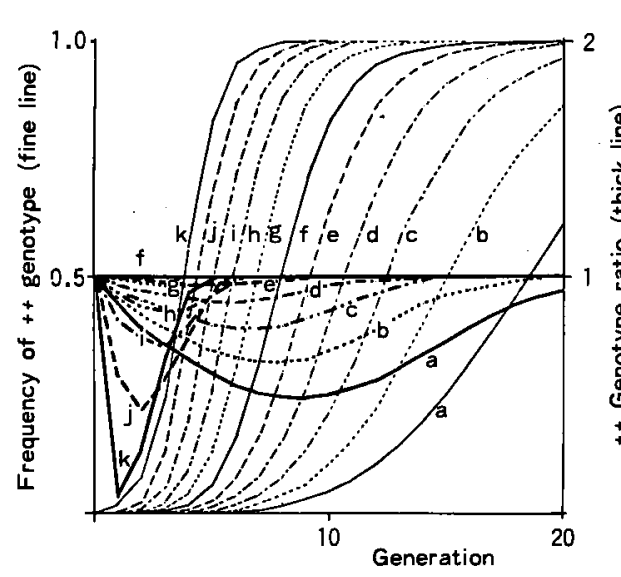

Fig. 1. The influence of $Q_{4} /\left(Q_{2}+Q_{4}\right)\left(Q+Q_{4}\right)$ on ++ genotype frequency and ++ genotype ratio. $I$.

Common conditions for all curves, $\mathrm{p}_{1}=0.97989745, \mathrm{p}_{2}=\mathrm{p}_{3}=0.01, \mathrm{p}_{4}=0.00010205$ (starting point)

$$
\begin{aligned}
& \mathrm{r}_{1}=\mathrm{r}_{2}=\mathrm{r}_{3}=\mathrm{r}_{4}=1 \\
& \mathrm{~s}_{1}=\mathrm{s}_{2}=\mathrm{s}_{3}=\mathrm{s}_{4}=1 \\
& \mathrm{q}_{2}=\mathrm{q}_{3}=0.25 \\
& \quad \text { Special condition }
\end{aligned}
$$

$\begin{array}{cccc} & \mathrm{q}_{1} & \mathrm{q}_{4} & \mathrm{Q}_{4} /\left(\mathrm{Q}_{2}+\mathrm{Q}_{4}\right)\left(\mathrm{Q}_{3}+\mathrm{Q}_{4}\right) \\ \mathrm{a} & 0.00 & 0.50 & 0.889 \\ \mathrm{~b} & 0.05 & 0.45 & 0.918 \\ \text { c } & 0.10 & 0.40 & 0.947 \\ \mathrm{~d} & 0.15 & 0.35 & 0.972 \\ \text { e } & 0.20 & 0.30 & 0.992 \\ \text { f } & 0.25 & 0.25 & 1.000 \\ \text { g } & 0.30 & 0.20 & 0.988 \\ \text { h } & 0.35 & 0.15 & 0.938 \\ \text { i } & 0.40 & 0.10 & 0.816 \\ \text { j } & 0.45 & 0.05 & 0.556 \\ \text { k } & 0.50 & 0.00 & 0.000\end{array}$

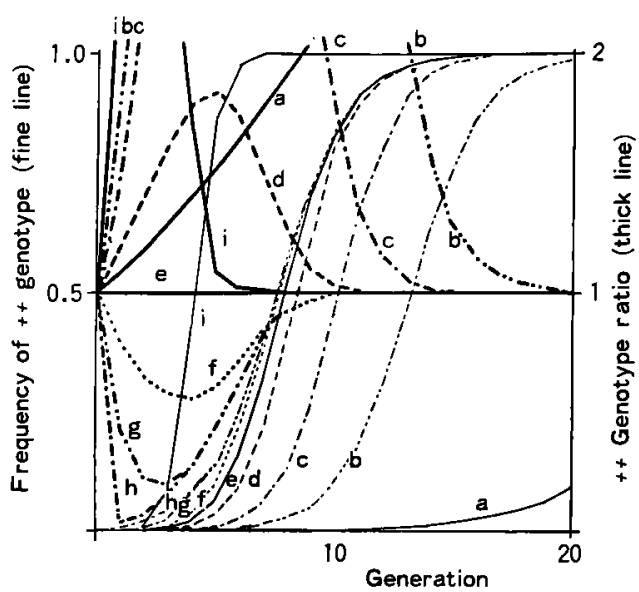

Fig. 2. The influence of $Q_{4} /\left(Q_{2}+Q_{4}\right)\left(Q_{3}+\right.$ $\mathrm{Q}_{4}$ ) on ++ genotype frequencies and ++ genotype ratio. II.

Common conditions for all curves. $\mathrm{p}_{1}=0.97989745, \mathrm{p}_{2}=\mathrm{p}_{3}=0.01, \mathrm{p}_{4}=0.00010205$ $r_{1}=r_{2}=r_{3}=r_{4}=1$ (starting point) $\mathrm{s}_{1}=\mathrm{s}_{2}=\mathrm{s}_{3}=\mathrm{s}_{4}=1$

Special condition

$\begin{array}{cccccc} & \mathrm{q}_{1} & \mathrm{q}_{2} & \mathrm{q}_{3} & \mathrm{q}_{4} & \mathrm{Q}_{4} /\left(\mathrm{Q}_{2}+\mathrm{Q}_{4}\right)\left(\mathrm{Q}_{3}+\mathrm{Q}_{4}\right) \\ \text { a } & 0.1 & 0.1 & 0.1 & 0.7 & 1.09 \\ \mathrm{~b} & 0.5 & 0.0 & 0.0 & 0.5 & 2.00 \\ \text { c } & 0.4 & 0.1 & 0.1 & 0.4 & 1.60 \\ \text { d } & 0.3 & 0.2 & 0.2 & 0.3 & 1.20 \\ \text { e } & 0.25 & 0.25 & 0.25 & 0.25 & 1.00 \\ \text { f } & 0.2 & 0.3 & 0.3 & 0.2 & 0.80 \\ \text { g } & 0.1 & 0.4 & 0.4 & 0.1 & 0.40 \\ \text { h } & 0.0 & 0.5 & 0.5 & 0.0 & 0.00 \\ \text { i } & 0.7 & 0.1 & 0.1 & 0.1 & 2.50\end{array}$

By equation ( 3 ),

$$
\mathrm{p}_{4}{ }^{\prime}=0.00010205 \text {. }
$$

The influence of the values of Q's on the ++ genotype ratio was first studied under the condition, $r_{1}=r_{2}=r_{3}=r_{4}$ (Fig. 1).

When $Q_{1}=Q_{2}=Q_{3}=Q_{4}=0.25$, the ++ genotype ratio is 1 in the simulation. This is demonstrated mathematically, too. Under this condition, $Q_{4} /\left(Q_{2}+Q_{4}\right)\left(Q_{3}+Q_{4}\right)=1$

From equation (1),

$$
\begin{aligned}
& \mathrm{p}_{2}{ }^{\prime} \mathrm{p}_{3}{ }^{\prime}=0.25 \mathrm{p}_{2} \mathrm{p}_{3} /\left(0.25 \mathrm{p}_{1}+0.5 \mathrm{p}_{2}+0.5 \mathrm{p}_{3}+\mathrm{p}_{4}\right)^{2} \\
& \mathrm{p}_{1}{ }^{\prime} \mathrm{p}_{4}{ }^{\prime}=0.25 \mathrm{p}_{1} \mathrm{p}_{4} /\left(0.25 \mathrm{p}_{1}+0.5 \mathrm{p}_{2}+0.5 \mathrm{p}_{3}+\mathrm{p}_{4}\right)^{2}
\end{aligned}
$$

Further, from the conditions of starting point, $\left(p_{2}+p_{4}\right)\left(p_{3}+p_{4}\right)=p_{4}$,

$$
\begin{aligned}
& p_{2} p_{3}+p_{2} p_{4}+p_{3} p_{4}+p_{4}{ }^{2}-p_{4}=0, \\
& p_{2} p_{3}+p_{2} p_{4}+p_{3} p_{4}-p_{4}\left(1-p_{4}\right)=p_{2} p_{3}+p_{2} p_{4}+p_{3} p_{4}-p_{4}\left(p_{1}+p_{2}+p_{3}\right)=0,
\end{aligned}
$$




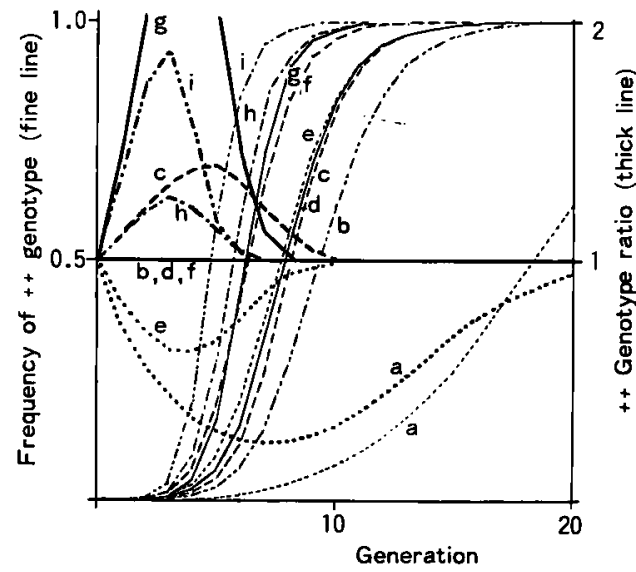

Fig. 3. The influence of $\mathrm{p}_{2} \mathrm{r}_{2} \mathrm{p}_{3} \mathrm{r}_{3} / \mathrm{p}_{1} \mathrm{r}_{1} \mathrm{p}_{4} \mathrm{r}_{4}$ on ++ genotype frequency and ++ genotype ratio

Common conditions

$\mathrm{p}_{1}=0.97989745, \mathrm{p}_{2}=\mathrm{p}_{3}=0.01, \mathrm{p}_{4}=0.00010205$

$\mathrm{q}_{1}=\mathrm{q}_{2}=\mathrm{q}_{3}=\mathrm{q}_{4}=0.25$

(starting point)

$\mathrm{s}_{1}=\mathrm{s}_{2}=\mathrm{s}_{3}=\mathrm{s}_{4}=1$

Special condition

$\begin{array}{cccclc} & \mathrm{r}_{1} & \mathrm{r}_{2} & \mathrm{r}_{3} & \mathrm{r}_{4} & \mathrm{r}_{2} \mathrm{r}_{3} / \mathrm{r}_{1} \mathrm{r}_{4} \\ \mathrm{a} & 1.0 & 0.9 & 0.9 & 0.6 & 1.35 \\ \mathrm{~b} & 1.0 & 0.9 & 0.9 & 0.81 & 1.00 \\ \mathrm{c} & 1.0 & 0.9 & 0.9 & 0.9 & 0.90 \\ \mathrm{~d} & 1.0 & 1.0 & 1.0 & 1.0 & 1.00 \\ \mathrm{e} & 1.0 & 1.2 & 1.2 & 1.2 & 1.20 \\ \mathrm{f} & 1.0 & 1.2 & 1.2 & 1.44 & 1.00 \\ \mathrm{~g} & 1.0 & 0.9 & 0.9 & 1.2 & 0.675 \\ \mathrm{~h} & 1.0 & 1.2 & 1.2 & 1.6 & 0.90 \\ \mathrm{i} & 1.0 & 1.2 & 1.2 & 2.0 & 0.72\end{array}$

$\therefore \mathrm{p}_{2} \mathrm{p}_{3}=\mathrm{p}_{1} \mathrm{p}_{4}$.

Accordingly, $\quad \mathrm{p}_{2}{ }^{\prime} \mathrm{p}_{3}{ }^{\prime}=\mathrm{p}_{1}{ }^{\prime} \mathrm{p}_{4}{ }^{\prime} . \quad$ Therefore, equation (4) is substantiated.

As shown in Fig. 1, the ++ genotype ratio decreases temporarily with increase of $\mathrm{Q}_{1}$ or decrease of $\mathrm{Q}_{4}$ from 0.25 when $\mathrm{Q}_{2}=\mathrm{Q}_{3}=0.25$. The increase of $\mathrm{Q}_{1}$ moves the minimum point towards earlier generation, and the increase of $\mathrm{Q}_{4}$ from 0.25 towards later generation with lowering of minimum point. In all cases, the curves of the ++ genotype ratio finally become 1 .

When $\mathrm{Q}_{1}$ to $\mathrm{Q}_{4}$ change at $\mathrm{Q}_{2}=\mathrm{Q}_{3}$ (Fig 2), the decrease of $Q_{2}$ and $Q_{3}$ from 0.25 induces an ascent of maximum point of the ++ genotype ratio, and the increase of $Q_{2}$ and $Q_{3}$ from 0.25 brings a descent of the minimum points. This corresponds to the increase of $Q_{4} /\left(Q_{2}+Q_{4}\right)\left(Q_{3}+Q_{4}\right)$ when $\mathrm{Q}_{2}=\mathrm{Q}_{3}<0.25$ and the decrease when $\mathrm{Q}_{2}=$ $\mathrm{Q}_{3}>0.25$.

The influence of $r$ 's values on the ++ genotype-ratio curves is illustrated in Fig. 3. The decrease of $\mathrm{r}_{2} \mathrm{r}_{3} / \mathrm{r}_{1} \mathrm{r}_{4}$ value from 1 brings the rise of the maximum point of the ++ genotype-ratio curve and the increase does the lowering of the minimum points.

All the results of these simulations indicate that all the ++ genotype-ratio curves become 1 asymptotically after temporary increase or decrease of them, as far as the

simulations mentioned above are concerned. In all these cases, frequencies of ++ genotype increase without exception. When the multiplication ability of ++ genotype is low as compared with multiplication abilities of other genotypes, the frequency of ++ genotype decreases. In such cases, the ++ genotype-ratio curves are asymptotic to 0 .

New information obtained from these simulations is that the ++ genotype-ratio curve becomes asymptotically 1 in many cases. Wolfe et al. ${ }^{12)}$ mentioned that if there is no selection, the frequency of ++ genotype should be equal to the product of frequencies of each virulence gene, that is, $\left(\mathrm{p}_{2}{ }^{\prime}+\mathrm{p}_{4}{ }^{\prime}\right)\left(\mathrm{p}_{3}{ }^{\prime}+\mathrm{p}_{4}{ }^{\prime}\right)=\mathrm{p}_{4}{ }^{\prime}$. The results of the present studies indicate that such equality is also obtained after directional and stabilizing selections as defined by van der Plank ${ }^{132}$. This indecates that equality of the ratio to 1 does not always show the absence of selections. Therefore, this largely restricts the use of virulence analysis. 


\section{Discussion}

The simulations in the present paper indicated that the frequencies of ++ pathogen genotype equal the product of frequencies of individual virulence genes not only under the conditions mentioned in the introduction but also even after directional and stabilizing selections unless the multiplication ability of the ++ genotype is low in comparison with ones of other genotypes. On the other hand, the ++ genotype ratios during seven years from 1959 to 1965 are greater than 1 . The simulations and mathematical studies indicate that the value of the ratio greater than 1 is obtained when

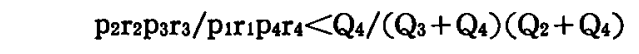

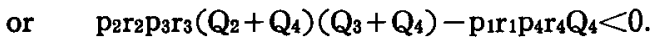

The percent growing areas of genotypes, $P i-i P i-k, P i-i+,+P i-k$ and ++ , in Japan in 1962 were $0,0.0192,0.0042$ and 0.9766 . Varieties with $P i-k$ resistance gene was released in 1960 first in Japan. There are no knowledge on the field susceptibility of these genotypes, although many varieties belonging to $P i-i^{+} P i-k$ genotype have high field susceptibility ${ }^{3)}$. Assuming that the field susceptibility of $+P i-k$ genotype is 2 times of ones of other host genotypes, that is, $\mathrm{s}_{1}=\mathrm{s}_{2}=\mathrm{s}_{4}=1$ and $\mathrm{s}_{3}=2$,

$$
\mathrm{Q}_{1}=0, \mathrm{Q}_{2}=0.0191, \mathrm{Q}_{3}=0.0084, \mathrm{Q}_{4}=0.9725
$$

are obtained. From these values,

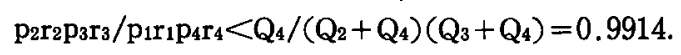

If the two virulence genes, $A v-i^{+}$and $A v-k^{+}$, occur independently,

$$
\mathrm{p}_{2} \mathrm{p}_{3}=\mathrm{p}_{1} \mathrm{p}_{4} \text {. }
$$

Then $\mathrm{r}_{2} \mathrm{r}_{3}<0.9914 \mathrm{r}_{1} \mathrm{r}_{4}$.

If multiplication ability of each pathogen genotype decreased by acquirement of virulence, and interaction of two virulence genes on multiplication ability is multiplicative,

$$
\left(r_{2} / r_{1}\right)\left(r_{3} / r_{1}\right)=r_{4} / r_{1}
$$

should be obtained. Therefore, $\mathrm{r}_{2} \mathrm{r}_{3}=\mathrm{r}_{1} \mathrm{r}_{4}$.

Accordingly, the assumption is not the case in the example mentioned above.

On the other hand, the regression coefficients of ++ genotype frequency on years were negative in all prefectures except Hokkaido. This indicates that $r_{4}$ is lower than $r$ 's of other genotypes. These conditions cannot, however, explain high frequencies of ++ genotype around 1959 in many prefectures. The simplest explanation for this discrepancy is invasion of fungus from outside sources, especially from foreign countries but not neiboring prefectures in Japan. Other explanation is that there was environmental conditions favorable for the ++ genotype in Japan in an earlier year than 1959. An exclusive explanation cannot be chosen in the present paper.

Virulence analyses of the data in Niigata and Toyama Prefectures showed significant differences between expected and observed frequencies of ++ genotype $[(\mathrm{a}++)+(+++)$ in the Table], especially during three years from 1964 to 1966 in spite of the absence of such difference in 1963 and 1969 . These significant differences are characterized by the increase of observed frequencies of ++ genotypes and the decrease of $A v-i A v-k$ genotypes compared with expected frequencies.

A similar tendency was found in the data in Yamagata Prefecture. Accumulation of 
data is required to know whether or not these results are due to the change of the ++ genotype ratio by such selections as shown in the simulations.

The ++ genotype ratio approaches to 1 even after selection due to cultivation of resistant varieties and/or the difference of fitness between fungus strains. This must be added to the conditions for the equality between ++ genotype frequency and the product of individual virulence gene frequencies, mentioned in the Introduction. This limits greatly the use of the virulence analysis. On the other hand, the use of ++ genotype ratio in simulation of change of pathogen genotype frequencies is effective to reduce the range of values given in parameters as used in the present paper. Synthetically, the virulence analysis is useful to search for causes of race frequency change, when combined with other methods including simulation.

\section{Literature cited}

1. Crow, J. F. and Kimura, M. (1970). Introduction to Population Genetics Theory. Harper \& Row, Publishers, New York, Evanston and London, p. 591.

2. Goto. K. (ed.) (1964). Special Report on the Forecasting of Occurrence of the Diseases and Insect Pests 18, Joint Work on the Race of Blast Fungus, Piricularia oryzae. (Fascicle 2). pp. 1-132 (In Japanese).

3. Hirano. T., Uchiyamada, H., Shindo, K., Matsumoto, A. and Akama, Y. (1967). Adv. Rept. Tohoku Natl. Agr. Expt. Sta. $7:$ 17-21 (In Japanese).

4. Kiyosawa, S. (1967). Proc. Symp. "Rice Diseases and Their Control by Growing Resistant Varieties and Other Measures". Tokyo 137-153.

5. Kiyosawa, S. (1981). Agr. Hort. (In press).

6. Kiyosawa, S., Matsumoto, S. and Lee, S.C. (1967). Japan. J. Breed. 17: 1-6.

7. Kiyosawa, S. and Yabuki, S. (1976). Agr. Hort. 51: 571-572 (In Japanese).

8. Kiyosawa, S. and Yabuki, S. (1976). Japan. J. Breed. $26: 237-246$.

9. Kiyosawa, S., Yasuda, H. and Shintani, I. (1977). Ann. Phytopath. Soc. Japan 43 : 508-516.

10. Kozaka, T. (ed.) (1972). Special Report on the Forecasting of Occurrence of the Diseases and Insect Pests 24, Joint Work on the Race of Blast Fungus, Pyricularia oryzae. (Fascicle 3). pp. 1-296 (In Japanese).

11. MacKenzie, D. R. (1979). Rice Blast Workshop. IRRI 199-216.

12. Matsumoto, N., Kiyosawa, S., Terasawa, M. and Inoue, M. (1979). Bull. Ishikawa Agr. Expt. Sta. $10: 1-16$ (In Japanese).

13. Van der Plank, J.E. (1968). Disease Resistance in Plant. Academic Press, New York and London, p. 206.

14. Wolfe, M. S., Barrett, J. A., Shattock, R.C., Shaw, D.S. and Whitbred, R. (1976). Ann. Appl. Biol. 82 : 369-374.

15. Wolfe, M.S. and Schwarzbach, E. (1975). Phytopathol. Z. 82 : 297-307.

16. Yabuki, S. and Kiyosawa, S. (1975). Research on Actual Condition of Severe Outbreak of Rice Blast. Kanagawa Prefecture 53-63 (In Japanese).

17. Yamada, M. and Iwano, M. (1972). Proc. 1st Congr. IAMS Vol. I: 425-435.

18. Yamada, M., Kozaka, T. and Matsumoto, S. (1972). In Special Report on the Forecasting of Occurrence of the Diseases and Pests 24, Joint Work on the Race of Blast Fungus, Pyricularia oryzae (Fascicle 3) (KozAKA, T. ed.). pp. 66-76.

19. Yamasaki, Y. and Kiyosawa, S. (1966). Bull. Natl. Inst. Agr. Sci. D14 : 39-69 (In Japanese).

20. Yanagita, K., Yaegashi, H. and Mogi, S. (1972). Bull. Tohoku Natl. Agr. Expt. Sta. 43: 31-42 (In Japanese).

21. Yaoita, T., Iwata, K., Yamada, M. and Iwano, M. (1977). J. Niigata Agr. Expt. Sta. 26: 53-62 (In Japanese). 
和 文 摘 要

\section{病原菌のレース頻度の病原性分析について}

\section{清 沢茂 久}

日本におけるいもち病菌のレース分布に関する既往のデーターを用いて病原性分析を行い，次の点を明ら かにした。日本各地方に批りる $A v-i^{+} A v-k^{+}$遗伝子型 (十+遗层子型) 頻度（観察値）はそれぞれの遗层子 頻度（ $A v-i^{+}$遗伝子頻度と $A v-k^{+}$遗伝子頻度）の積 ( ++ 遗伝子型頻度の期待值) よりも大きく, 両者の比 （十+遺伝子型比）は1より大きい值を示した。また $A v-i^{+}$䕗伝子頻度や $A v-k^{+}$遗伝子頻度や $A v-i^{+} A v-k^{+}$ 䢥卮子型頻度は1959年から1965年の間减少の傾向を示した。新潟県, 富山県, 山形県, 神奈川県のレースに 関するデーターでは種々の遺伝子型で上記の期待値と観察值の間に有意な美が認められた。この観察值と期 待値の比(十+遺云子型比) は $\mathrm{p}_{2} \mathrm{r}_{2} \mathrm{p}_{3} \mathrm{r}_{3} / \mathrm{p}_{1} \mathrm{r}_{1} \mathrm{p}_{4} \mathrm{r}_{4}<\mathrm{Q}_{4} /\left(\mathrm{Q}_{2}+\mathrm{Q}_{4}\right)\left(\mathrm{Q}_{3}+\mathrm{Q}_{4}\right)$ のときより大きくなり， $\mathrm{p}_{2} \mathrm{r}_{2} \mathrm{p}_{3} \mathrm{r}_{3}$ $/ \mathrm{p}_{1} \mathrm{r}_{1} \mathrm{p}_{4} \mathrm{r}_{4}>\mathrm{Q}_{4} /\left(\mathrm{Q}_{2}+\mathrm{Q}_{4}\right)\left(\mathrm{Q}_{3}+\mathrm{Q}_{4}\right)$ のとき1より小さくなる。しかしこの比は安定化選択や定向的選択の後に も 1 に戻る*。前述の日本各地に拈いて+十遺伝子型比が 1 より高い点, ++ 遺伝子型頻度が最初高くて徐々 に減少する点は単純な定向的選択や安定化選択では説明できないこのことはレース頻度の研究における病 原性分析の利用範冊をせばめるが，十+遺伝子型比は険討すべき要因の種類や範囲を減じらるためレース頻 度の研究に利用しらる。

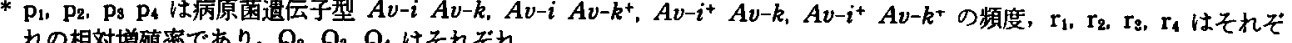
れの相対增殖率であり，Q2、Q

$\mathrm{Q}_{2}=\mathrm{q}_{2} \mathrm{~s}_{2} /\left(\mathrm{q}_{1} \mathrm{~s}_{1}+\mathrm{q}_{2} \mathrm{~s}_{2}+\mathrm{q}_{3} \mathrm{~s}_{3}+\mathrm{q}_{4} \mathrm{~s}_{4}\right)$

$Q_{8}=q_{3} s_{3} /\left(q_{1} s_{1}+q_{2} s_{2}+q_{8} s_{8}+q_{4} s_{4}\right)$

$Q_{4}=q_{4} s_{4} /\left(q_{1} s_{1}+q_{2} s_{2}+q_{8} s_{8}+q_{4} s_{4}\right)$

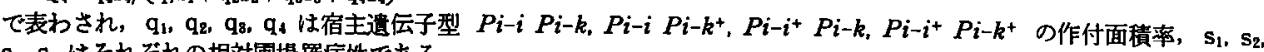
Ss. s、はそれそれれの相対阑場䍜病珄である。
} 